\title{
The Influence of Brand Personality Dimensions on Brand Identification and Word-of-Mouth: The Case Study of a University Brand in Thailand
}

\author{
Kawpong Polyorat \\ Khonkaen University, Thailand
}

\begin{abstract}
Brand personality refers to personality traits associated with a brand. The results of the study conducted in Thailand, where academic research in this area is scant, reveal that, for a university brand, brand personality dimensions of sincerity and competence have more influence on brand identification and word-of-mouth than the dimensions of excitement and sophistication. In addition, brand identification appears to mediate the influence of these two dimensions of brand personality on word-of-mouth. Implications and future study directions conclude the study report.
\end{abstract}

Keywords: Brand personality, Brand identification, Word-of-mouth, Thailand, University

\section{Introduction}

Brand personality has attracted interests from marketing researchers for several decades (Rojas-Mendez et al., 2004). Earlier research in brand personality examined different brands in several product categories and demonstrated that consumers perceived brands in terms of five orthogonal personality dimensions: sincerity (e.g. Hallmark), competence (e.g. The Wall Street Journal), excitement (e.g. MTV), sophistication (Guess), and ruggedness (e.g. Marlboro)(Monga and Lau-Gesk, 2007). This stream of research, however, focused on brands predominantly characterized by one single dimension of brand personality (Monga and Lau-Gesk, 2007) while a brand may simultaneously possess multiple dimensions of brand personality. The relative impact of each dimension of brand personality has been largely unexplored. The current study aims to fill in this gap. 
From a managerial perspective, this study also seeks to extend brand personality research into a non-profit organization such as an academic institution. Specifically, the current study attempts to investigate the impact of different brand personality dimensions of a university on two important outcome variables: brand identification and word-of-mouth.

In addition, to contribute to the cross-cultural marketing literature, the present investigation is conducted in Thailand, an Asian country where scholarly research in brand personality is scarce (Polyorat et al., 2008). Several studies (Aaker and Maheswaran, 1997; Aaker and Schmitt, 2001; Jung et al., 2009) have documented the differences between the behaviors of Asian and those of Western consumers. As a result, more research to better understand consumer behaviors in an international context is needed. The present study is one step toward such direction.

This research article is structured as follows. First, the situation of university branding in Thailand and literature in brand personality, brand identification, and word-ofmouth are reviewed. Next, a set of research hypotheses are offered and then empirically examined using survey research. Subsequently, data are analyzed and discussed. Finally, research implications and avenues for future research are suggested.

\section{Theoretical Background}

\section{Current Situation of University Branding in Thailand}

The use of Thailand as a country of focus is suitable for the context of the present study, which is university branding, because at present more universities in Thailand have attempted to employ several marketing strategies to draw more attention and interest from their major consumers - students. A survey of local magazines and newspapers (FourP, 2007; Komchudleuk Education, 2009; Marketeer, 2007) reveals increasing competitions among universities in Thailand. For example, several foreign universities, especially from the West, have recently opened their campuses in Thailand. These foreign players tend to bring with them the marketing-oriented practices such as branding which is common in their home countries. Further, numerous public Thai universities have become more modernized or some have been privatized, resulting in higher needs to attract more students to bring in more revenue for the university. The private universities themselves also respond to this competitive intensity through such marketing gimmicks as the provision of laptops for students, heavy advertising in various media, event marketing and sponsorships in order to strengthen their university brand.

In a global context, branding in higher education has become inevitable. Several universities have allocated their resources to build and maintain their brands (Chapleo, 2007). For example, a number of UK universities have a position for marketing director to "guard" their brand (Temple, 2006). Universities in Thailand follow this trend, university branding. Cursory scanning of local newspapers and 
magazines reveals numerous examples of heightening significance of university branding. For instance, an advertisement for a university states that "...XXXX is a modern, dynamic, challenging and exciting college that reflects the fast-moving world..." (FourP, 2007). Another example includes "Making You Outstanding with Supremacy" as the headline of the advertisement. In its copy is the elaboration of the claims "...offers cutting-edge education to create business leaders for today's fast changing environment..., lectured by highly-qualified faculty members from many countries in state of the arts classrooms..., collaborates with world-class university..." (Marketeer, 2007). These marketing tactics reflect the importance of brand building for universities as they can demonstrate various personalities of the universities. From this view, the present study would provide a number of managerial implications for universities wishing to build, strengthen, or refresh their brand.

\section{Brand Personality}

Brand personality refers to personality traits associated with a brand (Aaker, 1997). Brand personality, as a characterization of a brand (e.g. youthful) is a major component of brand image, in addition to the product's physical attributes (e.g. green in color) and the product's benefits (e.g. cleans teeth more effectively; Diamantopoulos et al., 2005). Because brand personality is likely to be more difficult to imitate than tangible product attributes, marketing practitioners may use it to achieve a more sustainable advantage (Ang and Lim, 2006) such as in product differentiation and positioning.

Through a series of studies, Aaker (1997) has uncovered five dimensions of brand personality: sincerity (down-to-earth, honest, wholesome and cheerful), excitement (daring, spirited, imaginative and up-to-date), competence (reliable, intelligent and successful), sophistication (upper class and charming) and ruggedness (outdoorsy and tough). These five dimensions are reported to be robust across the male sub-sample, female sub-sample, younger sub-sample and older sub-sample. These five dimensions emerge from different sets of brands and different sets of product categories, thus suggesting the scale generalizability. Despite some criticisms, most of the brand personality studies conducted after 1997 is based on Aaker's (1997) scale (Azoulay and Kapferer, 2003). Following previous studies in university brand personality (Opoku et al., 2006, 2008), the present study will use Aaker's framework - the five brand personality dimensions - as it appears to be relevant for the marketing of higher academic institutions.

\section{Brand Identification}

Brand identification occurs when consumers believe that they belong to a particular brand (Bhattacharya et al., 1995) and use the brand for self-referencing or selfdefining (Donavan et al., 2006). That is, consumers may have a strong emotional attachment with the brand and a sense of belonging to the brand. One source of social 
identity is the social categories to which consumers belong (Tajfel and Turner, 1985). In the context of the present study, these social categories can be based on organizational memberships such as a university or an academic institution. The present study attempts to examine the brand personality of the academic institution to which consumers (i.e. students) belong or with which ones identify (Pratt, 1998).

A number of research has suggested that brand identification is influenced by several factors including brand prestige, brand satisfaction, corporate communication, and brand attractiveness (Curras-Perez et al., 2009; Kuenzel and Halliday, 2009). Kim et al. (2001) indicated that the attractiveness and distinctiveness of brand personality influence brand identification and word-of-mouth. The current study attempts to extend this piece of finding by suggesting that certain dimensions of brand personality (i.e. sincerity and competence for a university brand) have more impacts on influencing brand identification and word-of-mouth. This research question is guided by Carlson et al.'s (2009) findings. Their study, in a sport context, reveals that the brand personality dimensions of imaginativeness and toughness positively influence identification while successfulness has a negative influence.

The hypothesis development in this study is based on the distinction between two consumption motives. On one hand, a utilitarian motive is primarily concerned with the functional or instrumental usefulness of the consumption which is derived from the product/service performance. On the other hand, a hedonic motive emphasizes the experiential pleasure derived from affective, esthetic, sensory and/or symbolic aspects of the consumption (Batra and Ahtola, 1991; Voss et al., 2003). The primary benefit of a university, as an educational institution, should primarily reflect the utilitarian motive where consumers (i.e. students) come to study, seek knowledge, augment their intellectual capabilities, and prepare themselves for future careers. As a consequence, the brand personality dimensions of sincerity and competence (vs. excitement and sophistication) which are relatively closer to the utilitarian motive are likely to have more influences on brand identification or students' identification with their academic institution. This hypothesis is, in part, derived from two findings in the marketing literature. First, an experimental study by Ang and Lim (2006) reveals that brand of symbolic or hedonic products (cologne and a designer watch) are perceived to be more sophisticated and exciting, but less sincere and competent than those of utilitarian products (mineral water and toothpaste). Second, a content analytic study by Polyorat and Thaikasame (2008) reveals that the majority of advertisements for utilitarian products employ rational advertising appeals while those for hedonic products primarily employ emotional or affective advertising appeals.

H1: For a university brand, brand personality dimensions of sincerity and competence will have more influences on brand identification than the dimensions of excitement and sophistication.

\section{Word-of-Mouth}

The success of a brand depends on bonds building with its consumers who, in turn, take part in multiple social networks where they could influence one another through word-of-mouth in the formation of consumption attitudes and behaviors (Allsop et al., 
2007). Word-of-mouth is an informal communication between consumers and consumers regarding the products or services, but not communication between consumers and marketing organizations such as complaints or promotions (Mazzarol et al., 2007). In comparison with marketer-initiated communication, word-of-mouth is less expensive (Villanueva et al., 2008), but more credible (Allsop et al., 2007). These advantages are attributable to the fact that the message is delivered personally and the message sender is not paid and often has only the best interest of the message recipient as the motivation for sharing an opinion (Etzel et al., 2007).

Given the important role of word-of-mouth as discussed above, it is pivotal to extend the current literature by examining if different dimensions of brand personality may have different impacts on word-of-mouth. The results of this research question will provide some guidelines on how to manage brand personality of a university to elicit word-of-mouth from their students.

As the utilitarian versus hedonic consumption benefit is found to have different impact on word-of-mouth (Chitturi et al., 2008), the line of reasoning similar to that of brand identification regarding the utilitarian versus hedonic motive of consumption is also used. Therefore, it is similarly expected that the brand personality dimensions of sincerity and competence (vs. excitement and sophistication) will have more influences on consumer's word-of-mouth (or students' positive talking about their university).

H2: For a university brand, brand personality dimensions of sincerity and competence will have more influences on word-of-mouth than the dimensions of excitement and sophistication.

Consumers who identify themselves with a particular brand are likely to experience a positively psychological outcome and, therefore, are more inclined to engage in favorable actions toward the brand (Donavan et al., 2006). Therefore, consumers' identification with a social object could lead to positive behaviors towards that social object (e.g. a group, an organization) (Kim et al., 2001). A number of studies (Bhattacharya and Sen 2003; Kuenzel and Halliday 2008; Mael and Ashforth, 1992) have suggested that identification with a brand may elicit favorable behaviors such as word-of-mouth. As a result, it is also expected that brand identification with a university will influence consumers' word-of-mouth. Based on H1 and H2, this impact is expected to mediate the influence of brand personality dimensions on wordof-mouth. This hypothesis regarding the mediating role of brand identification on the relationship between selected dimensions of brand personality and positive behaviors received preliminary support from Carlson et al.'s (2009) study. They report the influence of brand personality dimensions on retail spending and viewships through brand identification. The hypothesized relationships are visually displayed in Figure 1.

H3: Brand identification will mediate the influence of brand personality dimensions on word-of-mouth. 
Figure 1 Hypothesized Relationships

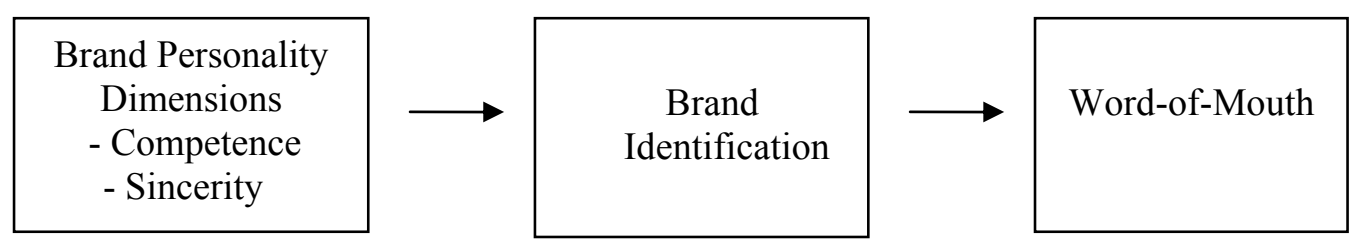

The dimensions of sincerity and excitement explain the largest variance in brand personality, followed by competence, sophistication, and ruggedness, respectively (Aaker, 1997). Because ruggedness accounts for the least amount of variance, it may be relevant for a smaller number of products or services in comparison with the other dimensions. As this study is exploratory, the formal hypotheses regarding the influences of the ruggedness dimension are not formulated but the data regarding this dimension will be also collected for exploratory purpose (Ang and Lim, 2006).

\section{Methodology}

\section{Overview}

A survey research was conducted to examine the relationships between independent variables (brand personality dimensions) and dependent variables (brand identification and word-of-mouth). After reliabilities of the measures being used are ascertained, a series of regression analyses were conducted to test the hypotheses following Baron and Kenny's (1986), Punjaisri and Wilson's (2007), and Sophonsiri and Polyorat's (2009) approach.

\section{Samples}

Data were collected from 357 undergraduate students attending a major Northeastern university in Thailand. The sample size was within the range identified in the literature (Tuntabundit and Polyorat, 2007) and the purposive sampling procedure was used following Tuntabundit and Polyorat (2007). All respondents were Thai. They filled out the survey during regular class hours. Subjects were first informed of the study description, then asked to complete the brand personality measure, brand identification measure and word-of-mouth measure, and provided personal data at the end. 


\section{Measures}

All original scales in English were translated to Thai using a back-translation procedure (Brislin, 1980). Brand personality was measured with Aaker's (1997) 42item Brand Personality Scale. The psychometric property of this scale with Thai consumers has been supported (Polyorat et al., 2008). The respondents were instructed to think of the brand of the university where they were studying as if it were a person and to rate on a five-point scale $(1=$ not at all descriptive, $5=$ extremely descriptive) the extent to which each of the 42 brand personality traits describes the brand. "Sincere", "exciting", "reliable", "glamorous", and "rugged" are examples of items used to assess the brand personality dimensions of sincerity, excitement, competence, sophistication, and ruggedness, respectively.

Brand identification was measured with six items adapted from Kim et al. (2001). Using five-point Likert scale where $1=$ strongly disagree and $5=$ strongly agree, respondents were asked to indicate the extent to which they agree or disagree with each of the six items. "The successes of XXX university are my success" and "When someone praised XXX university, it feels like a personal compliment" were examples of this scale.

Word-of-mouth was measured with three items adapted from Kim et al. (2001) also using five-point Likert scale where $1=$ strongly disagree and $5=$ strongly agree. "I recommend XXX university to other people" and "I talk about my experience with XXX university" were examples of this scale.

\section{Results}

Means, standard deviations, and reliabilities of the variables are displayed in Table 1. All scales exhibit Cronbach's alphas higher than 0.70. Further, Variation Inflation Factors were all lower than 0.36 in all three regression models which were well below the recommended cutoff point of 10 (Neter et al., 1985). This provides evidence that multicollinearity is not a problem in interpreting the results from regression parameter estimates.

Table 1 Descriptive Statistics and Reliabilities

\begin{tabular}{lccc}
\hline & Mean & SD & $\alpha$ \\
\hline Sincerity & 3.54 & 0.53 & 0.82 \\
Excitement & 3.62 & 0.63 & 0.91 \\
Competence & 3.85 & 0.62 & 0.91 \\
Sophistication & 3.25 & 0.72 & 0.88 \\
& 60 & &
\end{tabular}




\begin{tabular}{llll} 
Ruggedness & 3.52 & 0.77 & 0.87 \\
Brand Identification & 3.95 & 0.70 & 0.80 \\
Word-of-Mouth & 4.28 & 0.77 & 0.88 \\
\hline
\end{tabular}

Impact of dimensions of brand personality on brand identification (H1). To test this hypothesis, brand identification was regressed on sincerity, excitement, competence, sophistication, and ruggedness. The multiple regression results are shown in Table 2.

Table 2 Multiple Regression Results

\begin{tabular}{lcccccc}
\hline & \multicolumn{2}{c}{$\begin{array}{c}\text { (1) Brand } \\
\text { Identification }\end{array}$} & \multicolumn{2}{c}{ Mouth } & \multicolumn{2}{c}{ (2) Word-of-of- } \\
& \multicolumn{2}{c}{ Mouth } \\
\hline Independent Variables & .17 & $2.68^{* *}$ & .14 & $2.21^{*}$ & .05 & .98 \\
Sincerity & -.07 & -.79 & -.06 & -.71 & -.03 & -.36 \\
Excitement & .24 & $2.93^{* *}$ & .34 & $4.12^{* * *}$ & .22 & $3.01^{* *}$ \\
Competence & -.00 & -.16 & -.00 & -.01 & -.00 & -.02 \\
Sophistication & .18 & $3.01^{* *}$ & .09 & 1.40 & -.01 & -.14 \\
Ruggedness & --- & --- & --- & --- & .51 & $11.04^{* * *}$ \\
Brand Identification & -- & & &
\end{tabular}

Note: $* p<0.05, * * p<0.01 ; * *, p<0.001$ (two-tailed).

(1) $\mathrm{F}(5,351)=17.65, p<0.001, \mathrm{R}^{2}=0.20$, Adjusted $\mathrm{R}^{2}=0.19$

(2) $\mathrm{F}(5,351)=17.48, p<0.001, \mathrm{R}^{2}=0.20$, Adjusted $\mathrm{R}^{2}=0.19$

(3) $\mathrm{F}(6,350)=39.87, p<0.001, \mathrm{R}^{2}=0.41$, Adjusted $\mathrm{R}^{2}=0.40$

As expected, sincerity $(\beta=0.17, t=2.68, p<0.01)$ and competence $(\beta=0.24, t=$ $2.93, p<0.01)$ influenced brand identification while excitement $(\beta=-0.07, t=-0.79$, $p>0.1)$ and sophistication $(\beta=-0.00, t=-0.16, p>0.1)$ did not. Thus H1 is supported. For exploratory purpose, ruggedness $(\beta=0.18, t=3.01, p<0.01)$ was found to influence brand identification.

Impact of dimensions of brand personality on word-of-mouth (H2). To test this hypothesis, word-of-mouth was regressed on sincerity, excitement, competence, sophistication, and ruggedness. The multiple regression results are shown in Table 2.

As expected, sincerity $(\beta=0.14, t=2.21, p<0.05)$ and competence $(\beta=0.34, t=$ $4.12, p<0.001)$ influenced word-of-mouth while excitement $(\beta=-.06, t=-0.71, p>$ $0.1)$ and sophistication $(\beta=-0.00, t=-0.01, p>0.1)$ did not. Thus H2 is supported. For exploratory purpose, ruggedness $(\beta=0.09, t=1.40, p>0.1)$ was not found to influence word-of-mouth.

Mediating role of brand identification (BI) on the relationship between brand personality dimensions (BP) and word-of-mouth (WOM) (H3). To test the mediating role of brand identification, a series of regression analyses were run according to 
Baron and Kenny (1986). First, H2 was supported, indicating that sincerity and competence dimensions of brand personality had significant impact on word-ofmouth: BP $\rightarrow$ WOM. Second, in a simple regression analysis, brand identification was found to influence word-of-mouth $(\beta=0.60, t=14.21, p<0.001)$ : BI $\rightarrow$ WOM. Third, H1 was supported, indicating that sincerity, competence, and ruggedness dimensions of brand personality had significant impact on brand identification: BP $\rightarrow$ BI. Fourth, to test a mediating role of BI on BP-WOM relationship, word-of-mouth was regressed on both brand personality dimensions and brand identification. The results indicated that beta coefficients for BP dimensions have been reduced significantly enough to confirm mediation $\left(F_{6,350}=39.87\right.$, Adjusted $\mathrm{R}^{2}=0.40 ; \beta_{\text {sincerity }}$ $=0.05, t=0.98, p>0.1 ; \beta_{\text {excitement }}=-0.03, t=-0.36, p>0.1 ; \beta_{\text {competence }}=0.22, t=$ $3.01, \mathrm{p}<0.01 ; \beta_{\text {sophistication }}=-0.00, t=-0.02, p>0.1 ; \beta_{\text {ruggedness }}=-0.01, t=-0.14, p>$ $\left.0.1 ; \beta_{\mathrm{BI}}=0.51, t=11.04, p<0.001\right)$. As a result, $\mathrm{H} 3$ was supported.

\section{Discussions}

\section{Summary}

The study results reveal that, for a university brand, brand personality dimensions of sincerity and competence have more influences on brand identification and word-ofmouth than those of excitement and sophistication. In addition, brand identification appears to mediate the influence of brand personality dimensions on word-of-mouth. The ruggedness dimension, although not formally hypothesized, is found to influence brand identification but not word-of-mouth.

\section{Theoretical Implications}

This study provides both theoretical and managerial contributions to the areas of marketing and consumer behavior. In terms of theoretical implications, the current study suggests that each dimension of brand personality may exhibit different levels of influence on consumer behavior depending on the consumption motive or the characteristics of a product or service. For a product/service consumed primarily for utilitarian benefits such as a university in the present study, the dimensions of competence and sincerity (vs. excitement and sophistication) are found to have more impacts on brand identification and word-of-mouth. The results of the present study are, thus, in line with Ang and Lim's (2006) study although the focal products or services (university vs. mineral water, toothpaste), as well as the methodology (survey vs. experiment), are different. Future research may examine an institution or organization where the primary consumption motive is hedonic to complement the findings of the present study. In addition, the present study supports Aaker's (1997) view of brand personality. That is, more brand personality studies are needed at the dimension level because each dimension may have different importance or relevance for varied product/service categories. As a consequence, the present study suggests 
that, when a brand personality study is to be conducted, the focal dimensions of interest need to be specified.

Next, the study results contribute to the brand identification and word-of-mouth literature by suggesting dimensions of brand personality as one of their antecedents. Our results concerning the relationship between brand identification and word-ofmouth is consistent with those of Kim et al.'s (2001) study, therefore suggesting the external validity of the results across product categories (university and cell phone), across cultures (Thailand and Korea), and across different levels of brand personality analysis (dimension level and aggregate level).

The present study also contributes to the cross-cultural consumer behavior area by examining the brand personality construct in Thailand, an underrepresented country in the cross-cultural research literature (Polyorat et al., 2008). This study provides empirical evidence regarding the relative importance of five dimensions of brand personality in Asia in general and in Thailand in particular. The results of the current study corroborate with those of the studies conducted in the western part of the world (Opoku et al., 2008) by demonstrating the applicability of Aaker's (1997) five brand personality dimensions for institutions of higher education.

\section{Managerial Implications}

The present study demonstrates the differential importance of each brand personality dimension in eliciting consumer's favorable reaction toward the brand of an academic institution. Moreover, the present study provides supporting evidence that brand identification is an important component for an academic institution to achieve a distinct identity and competitive advantage (Nandan, 2005) for desirable consumer behaviors such as positive word-of-mouth.

The results, hence, suggest possible guidelines on how to increase students' willingness to contribute to their university (Shamir, 1990). For example, in terms of fundraising, the university management may wish to focus on certain dimensions of brand personality (i.e. competence and sincerity) when approaching alumni to increase the brand identification (Mael and Ashforth, 1992). For the current students as well as alumni, the focus on certain dimensions could increase the sale of school merchandise such as gifts with university logos (Donavan et al., 2006).

With the increasing role of word-of-mouth via information communication channels such as emails, cell phones, and blogs (Allsop et al., 2007), the university management may consider putting special effort into managing their selected dimensions of university brand personality. For instance, via these channels, university marketing practitioners may want to focus on the sincerity and competence dimensions of brand personality during their interaction with students over the longterm period. This decision may encourage the consumers to increase their help to their institution by spreading more positive word-of-mouth and may even defend their university when it is negatively criticized. Because word-or-mouth is often more 
effective than traditional advertising in attitude change or formation (Hogan et al., 2004), marketing practitioners should allocate special attention to the selection of brand personality dimensions they want to focus to make the best use from their limited resources.

\section{Study Limitations and Avenues for Future Research}

As word-of-mouth could be viewed as connected to other consumer behaviors such as brand loyalty (Mazzarol et al., 2007) and complaints, future research may want to examine the impact of brand personality dimensions on these two outcomes. Furthermore, other dependent measures, especially conative ones such as symbol collecting and passing (Donavan et al., 2006) could be included because these behaviors are a mechanism through which consumers enhance their self-esteem (Burmann and Zeplin, 2005) and strengthen their sense of belonging to an academic institution. However, as more variables are included in the model, structural equation model (SEM) can be used to examine a complex set of relationship especially when the established scales are adapted in a study (Sophonsiri and Polyorat, 2009).

While the measure of brand identification exhibited Cronbach's alpha of 0.80 which could seem relatively modest in comparison with other scales used in the current study, it still achieved the level of 0.80 suggested by Nunnally (1978) for basic research. In addition, the mean alphas reported in a meta-analysis conducted by Peterson (1994) were lower than 0.80 for a scale comparable with brand identification measure in terms of sample size (300 or more), type of sample (college students), number of scale categories (five), number of items (six), scale type (Likert), scale format (only end points labeled), nature of scale (odd number of item categories), administration mode (self), scale orientation (respondent centered), nature of construct, and type of research. The brand identification measure in the current study is therefore deemed satisfactorily reliable. Future research, however, may further refine the scale to increase its reliability, using the guideline suggested by Peterson (1994).

Further, because the data in this study was collected from a single university, future research may be conducted on a larger scale by drawing study samples from several universities. This will enhance the generalizability of the study to better represent Thailand as a whole. Moreover, future research could also replicate this study in other countries with different cultures, religions, levels of economic development, and degree of exposure to globalization. For example, in an individualist culture where consumers tend to have dominant independent self-construal, reactions to a university brand composed of several dimensions of brand personality may be less favorable (Monga and Lau-Gesk, 2007).

Other types of institutions (Bhattacharya, 1995) such as an art museum, a political party, or an institution where hedonic motive could be more pronounced warrant more studies. Different dimensions of brand personality may exhibit different levels of influence for varied types of organizations. 
In addition to a survey method, other research methods including depth interview (Blythe, 2007), experiment (Monga and Lau-Gesk, 2007) and content analysis (Opoku et al., 2006) may provide additional explanations on the relative influences of each dimension of brand personality.

\section{Implications for Business Practice}

Brand personality refers to personality traits associated with a brand (Aaker, 1997). Brand personality is composed of five dimensions (Aaker, 1997): sincerity (down-toearth, honest, wholesome and cheerful), excitement (daring, spirited, imaginative and up-to-date), competence (reliable, intelligent and successful), sophistication (upper class and charming) and ruggedness (outdoorsy and tough). Brand identification occurs when consumers believe that they belong to a particular brand (Bhattacharya et al., 1995) and use the brand for self-referencing or self-defining (Donavan et al., 2006). Word-of-mouth is an informal communication between consumers and consumers regarding the products or services, but not communication between consumers and marketing organizations such as complaints or promotions (Mazzarol et al., 2007). The present study attempts to examine the impact of the different dimensions of brand personality on brand identification and word-of-mouth.

This study is conducted in Thailand where academic research in this area is scant. Using data from a survey research with 357 Thai undergraduate students, the results reveal that, for a university brand, brand personality dimensions of sincerity and competence have more influences on brand identification and word-of-mouth than those of excitement and sophistication. In addition, brand identification appears to mediate the influence of these two dimensions of brand personality on word-ofmouth. The utilitarian (vs. hedonic) consumption benefit of an academic institution is suggested to be the explanation of the study results.

This study demonstrates the differential importance of each brand personality dimension in eliciting consumer's favorable reaction toward the brand of an academic institution. Moreover, the present study provides supporting evidence that brand identification is an important component for an academic institution to achieve a distinct identity and competitive advantage for desirable consumer behaviors such as positive word-of-mouth.

The results, hence, suggest possible guidelines on how to increase students' willingness to contribute to their university (Shamir, 1990). For example, in terms of fundraising, the university management may wish to focus on certain dimensions of brand personality (i.e. competence and sincerity) to increase the brand identification which could finally result in favorable outcomes such as donations to ones' alma mater (Mael and Ashforth, 1992). For the current students as well as alumni, the focus on certain dimensions could increase the sale of school merchandise such as gifts with university logos (Donavan et al., 2006). 
With the increasing role of word-of-mouth via information communication channels such as emails, cell phones, and blog (Allsop et al., 2007), the university management may consider putting special efforts into their selected dimensions of university brand personality. For instance, via these channels, marketing practitioners may want to focus on the sincerity and competence dimensions of brand personality during their interaction with students. This decision could result in consumers' wish to increase their contributions to their institute by spreading more positive word-of-mouth and may even defend their university when it is negatively criticized. Because word-ormouth is often more effective than traditional advertising in attitude change or formation (Hogan et al., 2004), marketing practitioner should allocate special attention to the selection of brand personality dimensions they want to focus to make the best use from their limited resources.

\section{References}

Aaker, J.L. (1997), "Dimension of brand personality", Journal of Marketing Research, vol. 34, no. 3, pp. 347-356.

Aaker, J.L. and Maheswaran, D. (1997), "The effect of cultural orientation on persuasion", Journal of Consumer Research, vol. 24, no. 3, pp. 315-328.

Aaker, J.L. and Schmitt, B. (2001), "Culture-dependent assimilation and differentiation of the self preferences for consumption symbols in the United States and China", Journal of CrossCultural Psychology, vol. 32, no. 5, pp. 561-576.

Ang, S.H. and Lim, E.A.C. (2006), "The influence of metaphors and product type on brand personality perceptions and attitudes", Journal of Advertising, vol. 35, no. 2, pp. 39-53.

Allsop, D.T., Bassett, B.R. and Hoskins, J.A. (2007), "Word-of-mouth research: Principles and applications", Journal of Advertising Research, vol. 47, no. 4, pp. 398-411.

Azoulay, A. and Kapferer, J.N. (2003), "Do brand personality scales really measure brand personality?” Brand Management, vol. 11, no. 2, pp. 143-155.

Baron, R. and Kenny, D. (1986), "The moderator-mediator variable distinction in social psychological research: Conceptual, strategic, and statistical considerations", Journal of Personality and Social Psychology, vol. 51, no. 6, pp. 1173-1182.

Batra, R. and Ahtola, O.T. (1991), "Measuring the hedonic and utilitarian sources of consumer attitudes", Marketing Letters, vol. 2, no. 2, pp. 159-170.

Bhattacharya, C.B. and Sen, S. (2003), "Consumer-company identification: A framework for understanding consumers' relationships with companies", Journal of Marketing, vol. 67, no. 2, pp. 76-88. 
Bhattacharya, C.B., Rao, H. and Glynn, M.A. (1995), "Understanding the bond of identification: An investigation of its correlates among art museum members", Journal of Marketing, vol. 59, no. 4, pp. 46-57.

Blythe, J. (2007), "Advertising creatives and brand personality: A grounded theory perspective", Journal of Brand Management, vol. 14, no. 4, pp. 284-294.

Brislin, R.W. (1980), "Translation and content analysis of oral and written material" in Triandis, H.C. and Berry, J.W. (Eds.), Handbook of Cross-cultural Psychology, vol. 2, Ally \& Bacon, Boston, MA, pp. 389-444.

Burmann, C. and Zeplin, S. (2005), "Building brand commitment: A behavioral approach to internal brand management", Journal of Brand Management, vol. 12, no. 4, pp. 279-300.

Carlson, B.D., Donavan, D.T. and Cumiskey, K.J. (2009), "Customer-based relationships in sport: Brand personality and identification", International Journal of Retail \& Distribution Management, vol. 37, no. 4, pp. 370-384.

Chapleo, C. (2007), "Barriers to brand building in UK universities?" International Journal of Nonprofit and Voluntary Sector Marketing, vol. 12, no. 1, pp. 23-32.

Chitturi, R., Raghunathan, R. and Mahajan, V. (2008), "Delight by design: The role of hedonic versus utilitarian benefits", Journal of Marketing, vol. 72, no. 3, pp. 48-63.

Currás-Pérez, R., Bigné-Alcañiz, E. and Alvarado-Herrera, A. (2009), "The role of selfdefinitional principles in consumer identification with a socially responsible company", Journal of Business Ethics, vol. 89, no. 4, pp. 547-564.

Diamantopoulos, A., Smith, G. and Grime, I. (2005), "The impact of brand extensions on brand personality: Experimental evidence", European Journal of Marketing, vol. 39, no. 1/2, pp. 129-149.

Donovan, D.T., Janda, S. and Suh, J. (2006), "Environmental influences in corporate brand identification and outcomes", Brand Management, vol. 4, no. 1/2, pp. 125-136.

FourP (2007), vol. 4, no. 44, p. 89.

Etzel, M.J., Walker, B.J. and Stanton, W.J. (2007), Marketing, McGraw-Hill/Irwin, New York, NY.

Hogan, J.E., Lemon, K.N. and Libai, B. (2004), "Quantifying the ripple: Word-of-mouth and advertising effectiveness”, Journal of Advertising Research, vol. 44, no. 3, pp. 271-280.

Jung, J.M., Polyorat, K. and Kellaris, J.J. (2009), “A cultural paradox in authority-based advertising appeals”, International Marketing Review, vol. 26, no. 6, pp. 601-632.

Keller, K.L. (1993), "Conceptualizing, measuring, and managing customer-based brand equity”, Journal of Marketing, vol. 57, no. 1, pp. 1-22. 
Kim, C.K., Han, D. and Park, S.B., (2001), "The effect of brand personality and brand identification on brand loyalty: Applying the theory of social identification", Japanese Psychological Research, vol. 43, no. 4, pp. 195-206.

Komchudleuk Education (2009), September 2009.

Kuenzel, S. and Halliday, S.V. (2008), "Investigating antecedents and consequences of brand identification", Journal of Product \& Brand Management, vol. 17, no 5, pp. 293-304.

Mael, F. and Ashforth, B. (1992), "Alumni and their alma mater: A partial test of the reformulated model of organizational identification", Journal of Organizational Behavior, vol. 13, no. 2, pp. 103-123.

Marketeer (2007), vol. 8, no. 86, p. 3 .

Mazzarol, T., Sweeney, J.C. and Soutar, G.N. (2007), "Conceptualizing word-of-mouth activity, triggers and conditions: An exploratory study", European Journal of Marketing, vol. 41, no. 11/12, pp. 1475-1494.

Monga, A.B. and Lau-Gesk, L. (2007), "Blending cobrand personalities: An examination of the complex self”, Journal of Marketing Research, vol. 44, no. 3, pp. 389-400.

Nandan, S. (2005), "An exploration of the brand identity-brand image linkage: A communications perspective", Journal of Brand Management, vol. 12, no. 4, pp. 264-279.

Neter, J., Wasserman, W. and Kutner, M.H. (1985), Applied Linear Statistical Models: Regression, Analysis of Variance, and Experimental Designs, Richard D. Irwin, Homewood, IL.

Nunnally, J.C. (1978), Psychometric Theory, 2nd ed., McGraw-Hill, New York, NY.

Opoku, R., Abratt, R. and Pitt, L. (2006), "Communicating brand personality: Are the website doing the talking for the top South African business schools?" Brand Management, vol. 14, no. $1 / 2$, pp. 20-39.

Opoku, R., Hultman, M. and Saheli-Sangari, E. (2008), "Positioning in market space: The evaluation of Swedish universities' online brand personalities", Journal of Marketing for Higher Education, vol. 18, no. 1, pp. 124-144.

Peterson, R.A. (1994), “A meta-analysis of Cronbach's coefficient alpha”, Journal of Consumer Research, vol. 21, no 2, pp. 381-391.

Polyorat, K., Khantuwan, W., Jaratmetakul, P. and Boonnon, N. (2008), "Dimensions of brand personality in Thailand: Some empirical evidence" in Taylor, C.R., Schmitt, B., Wagner, U. and Jia, J. (Eds.), Proceedings of Global Marketing Conference, Korean Academy of Marketing Science, pp. 1-13.

Polyorat, K. and Thaikasame, S. (2008), "The influences of product types (high- vs. lowinvolvement, utilitarian vs. hedonic, and high vs. low social visibility) on the use of advertising types (rational vs. emotional and verbal vs. visual) in print ads: Evidence from Thailand" in Fuxman, L., Delener, N., Lu, F.V. and Rivera-Solis, L.E. (Eds.), Proceeding of 
the Global Business and Technology Association's Tenth Annual International Conference, the Global Business and Technology Association, pp. 1224-1231.

Pratt, M.G. (1998), "To be or not to be: Central question in organizational identification" in Whetten, D.A. and Godfrey, P.C. (Eds.), Identity in Organization: Building Theory through Conversations, Sage, Thousand Oaks, CA, pp. 171-207.

Punjaisri, K. and Wilson, A. (2007), "The role of internal branding in the delivery of employee brand promise", Brand Management, vol. 15, no. 1, pp. 57-70.

Rojas-Mendez, J.I., Erenchun-Podlech, I. and Silva-Olave, E. (2004), “The Ford brand personality in Chile", Corporate Reputation Review, vol. 7, no. 3, pp. 232-251.

Shamir, B. (1990), "Calculation, values, and identities: The sources of collectivistic work motivation”, Human Relations, vol. 43, no. 4, pp. 313-332.

Sophonsiri, S. and Polyorat, K. (2009), "The impact of brand personality dimensions on brand association and brand attractiveness: The case study of KFC in Thailand", Journal of Global Business and Technology, vol. 5, no. 2, pp. 51-62.

Tajfel, H. and Turner, J.C. (1985), "The social identity theory of intergroup behavior" in Worchel, S. and Austin, W.G. (Eds.), Psychology of Intergroup Relations, vol. 2, NelsonHall, Chicago, IL, pp. 7-24.

Temple, P. (2006), “Branding higher education: Illusion or reality?" Perspective, vol. 10, no. 1, pp. 15-19.

Tuntabundit, W. and Polyorat, K. (2007), "The comparison of brand personality of Siam commercial bank and Krungthai bank from the perception of Khonkaen university students", KKU Journal of Management Science, vol. 6, no. 2, pp.1-10.

Villanueva, J., Yoo, S. and Hanssens, D.M. (2008), "The impact of marketing-induced versus word-of-mouth acquisition on customer equity growth", Journal of Marketing Research, vol. 45 , no. 1 , pp. $48-59$.

Voss, K.E., Sprangenberg. E.R. and Grohmann, B. (2003), "Measuring the hedonic and utilitarian dimensions of consumer attitude", Journal of Marketing Research, vol. 40, no. 3 , pp. 310-320. 